\title{
Trypanosoma cruzi Mucins: Potential Functions of a Complex Structure
}

\author{
Igor C Almeida $/{ }^{+}$, Ricardo Gazzinelli*/**, Michael AJ Ferguson***, \\ Luiz R Travassos****
}

\begin{abstract}
Departamento de Parasitologia, ICB2, USP, 05508-900 São Paulo, SP, Brasil *Departamento de Bioquímica e Immunologia, UFMG, Belo Horizonte, MG, Brasil **Laboratorio de Doença de Chagas, CPqRR-Fiocruz, Belo Horizonte, MG, Brasil ***Department of Biochemistry, University of Dundee, Dundee, Scotland,United Kingdom ****Departamento de Immunologia, Microbiologia e Parasitologia, Unifesp, São Paulo, SP, Brasil
\end{abstract}

Key words: Trypanosoma cruzi - mucins - Chagas disease

The protozoan Trypanosoma cruzi, the etiological agent of Chagas disease (Chagas 1909), displays on its surface various glycoconjugates which appear to be involved in the recognition and invasion of mammalian host cells, as well as in establishing and sustaining the chronic infection (Travassos \& Almeida 1993). The majority of these molecules are attached to the parasite via a posttranslational modification of a glycosylphosphatidylinositol (GPI) anchor (Ferguson 1997). The two most abundant glycoconjugates present in all T. cruzi developmental stages are the glycoinositolphospholipids (GIPLs), of which the major constituent was formerly known as lipopeptidophosphoglycan (LPPG) (Lederkremer et al. 1976), and the mucin-like glycoproteins. The latter were first observed by Alves and Colli (1975) during the process of purification of epimastigote glycoproteins by gel chromatography. The mucin-like characteristics of these glycoconjugates was recognized by Schenkman et al. (1993) including their high content of hydrophilic amino acids (threonine, serine, lysine and glycine), $O$-linked oligosaccharides and sialic acids, typical features that define mammalian mucins. In T. cruzi, the mucins are the main acceptors of sialic acid via a trans-sialidase reaction (Previato et al. 1985, Zingales et al. 1987, Schenkman et al. 1991, 1993, 1994) which can use different $\alpha 2,3$-sialylated donors.

T. cruzi mucins migrate in SDS-polyacrylamide gels as double- or triple bands with apparent molecular mass of $35-43 \mathrm{kDa}$, in epimastigote, and $35-50 \mathrm{kDa}$, in metacyclic trypomastigote (Previato

This work is supported by Fapesp and CNPq (Brazil), and The Wellcome Trust (UK).

+Corresponding author. E-mail: ialmeida@icb.usp.br Received 9 June 1999

Accepted 9 August 1999 et al. 1985, Yoshida et al. 1989). In this insect-derived infective stage the $35-50 \mathrm{kDa}$ mucin-like glycoproteins seem to be implicated in the modulation of the processes of host cell adhesion and invasion (Ruiz et al. 1993, 1998, Yoshida et al. 1997). In tissue culture-derived trypomastigotes, $T$. cruzi mucins have a polydisperse migration of 60-200 $\mathrm{kDa}$ (Schenkman et al. 1991), with better resolution under special electrophoresis conditions yielding broad bands at 74,96 , and $120-200 \mathrm{kDa}$ (Almeida et al. 1993). In recent years, the composition and chemical structure of T. cruzi "mucins", particularly their $O$-linked oligosaccharides and GPI-anchors have been investigated (Schenkman et al. 1993, Previato et al. 1994, 1995, Almeida et al. 1994b, Serrano et al. 1995, Camargo et al. 1997). Epimastigote, tissue culture-derived trypomastigote and metacyclic trypomastigote mucins have oligosaccharide chains internally linked to $\mathrm{N}$ acetylglucosamine (GlcNAc) units $O$-glycosidically-linked to threonine, representing approximately $60 \%$ of the total mass of the glycoprotein (Previato et al. 1994, Almeida et al. 1994b, Serrano et al. 1995). These oligosaccharides are mostly branched and contain Galp, Galf, and sialic acid (SA) units besides $O$-linked GlcNAc in their composition. More recently, Previato et al. (1998) have characterized the activity of the enzyme uridine diphospho- $N$-acetylglucosamine: polypeptide- $\alpha$ $\mathrm{N}$-acetylglucosaminyltransferase $(O$-alphaGlcNAc-transferase), which is responsible for the transfer of GlcNAc to threonine residues of the mucin polypeptide chain during the biosynthesis of the $O$-linked oligosaccharides. This novel enzyme presents different catalytic properties when compared to the mammalian cell-derived $O$-betaGlcNAc transferase (Haltiwanger et al. 1992), and may represent an important target for the development of more specific drugs for the treatment of Chagas disease. A striking feature of these $O$-linked oligosaccharides is the presence of $\alpha$-galactopyranosyl residues exclusively in the oligosaccha- 
rides isolated from mucins of tissue culture-derived trypomastigotes. This clearly explains the strong recognition of mammalian cell-derived trypomastigotes by lytic anti- $\alpha$-galactosyl antibodies from patients with chronic Chagas disease (Ch anti-Gal) (Almeida et al. 1991, 1993, 1994a,b). Metacyclic trypomastigotes are also recognized and destroyed by lytic $\mathrm{Ch}$ anti-Gal, but the target epitope is a 72 kDa glycoprotein, which has not been structurally characterized (Travassos et al. 1993).

One of the main differences among mucins from the various stages resides on the phosphatidylinositol (PI) moiety of the GPI anchor, isolated by nitrous deamination. While the epimastigote mucin GPI contains mainly $1-O$ (C16:0)alkyl-2-O-(C16:0)acylglycerol-3-phospho1-myo-inositol, the metacyclic mucin anchor is predominantly formed by different species of phosphoceramide-inositol $(\sim 70 \%)$, containing dihydrosphingosine (C18:0) and lignoceric (C24:0) or palmitic acid (C16:0) (Serrano et al. 1995). Conversely, the PI isolated from the GPI anchor of mammalian cell-derived trypomastigote mucins are constituted by an alkylacyl-glycerol chain, containing mainly unsaturated fatty acid (C18:1 or C18:2) (Camargo et al. 1997).

Regarding the native mucin polypeptide chain, little is known at present. Available data are derived from the cloning and expression of mucin genes. T. cruzi mucins are transcribed from families of up to five hundred genes (Di Noia et al. 1998). Several of these genes have recently been cloned from epimastigote and trypomastigote genomic and cDNA libraries and had their polypeptide sequence deduced (Reyes et al. 1994, Di Noia et al. 1995, 1996, 1998, Salazar et al. 1996, FreitasJunior et al. 1998). From these studies, we can group the deduced polypeptide sequences into two major families. Family I polypeptides are formed by central domains rich in Thr, Lys and Pro, organized in blocks containing the repetitive motif $(\mathrm{Thr})_{8} \mathrm{Lys}(\mathrm{Pro})_{2}$. These central blocks are flanked by a highly variable and short (7-12 amino acid) $\mathrm{N}$-terminal region and a more conserved C-terminal region. Conversely, Family II polypeptides, despite showing $\mathrm{N}$ - and $\mathrm{C}$-terminal regions similar to Family I, they have not the repetitive $(\mathrm{Thr})_{8}$ Lys(Pro $)_{2}$ motifs. Furthermore, Family II has a much lower concentration of Thr residues than Family I (Di Noia et al. 1996). Recent unpublished observations from our group indicate that Family I sequences are expressed in epimastigotes and metacyclic mucins, whereas Family II are found in trypomastigote mucins and, possibly, amastigote mucins. This was assumed by comparing the amino acid composition of DNA-deduced sequences with that of native mucins purified from the four T. cruzi stages. We have also observed that epimastigote and metacyclic mucins, contrary to trypomastigote mucins, are almost completely resistant to trypsin digestion. This is compatible with the existence of central domains containing the motif $(\mathrm{Thr})_{8} \mathrm{Lys}(\mathrm{Pro})_{2}$ in mucins from insect-derived parasite stages. It is well documented in the literature that a Pro residue, located at the carboxy terminus of a Lys residue, can completely block the action of trypsin.

Recent studies show that mucins from trypomastigotes, but not from epimastigotes and metacyclic forms, can potently induce the synthesis of proinflammatory cytokines (TNF- $\alpha$, IL-12) and nitric oxide (NO) by IFN- $\gamma$-primed murine macrophages (Camargo et al. 1997a, 1997b, Gazzinelli et al. 1997). The strong inducing activity of the trypomastigote mucins is achieved at subpicomolar (0.01-0.1 pM) concentrations. Experimental evidence indicates that the mucin GPI contains the minimal structure responsible for its bioactivity. Chemical treatments, such as nitrous deamination and mild alkaline hydrolysis, under conditions that exclusively affect the GPI anchor structure can completely abolish the cytokine/NO inducing activity of trypomastigote mucins (Camargo et al. 1997). Recent observations clearly demonstrate that, indeed, a highly purified trypomastigote mucin GPI can strongly activate murine macrophages. The precise role of GPI-anchored trypomastigote mucins in the pathophysiology of experimental and human infection by $T$. cruzi is not known, but mucins induce several cytokines, such as IL-12 and TNF- $\alpha$, which are thought to be involved in protection and pathophysiology of experimental Chagas disease (Brener \& Gazzinelli 1997). We have also provided strong evidence that cyclic AMP modulates trypomastigote mucin-induced IL-12 production by macrophages indirectly, following the release of IL10 . In contrast, the effects of cyclic AMP regulation of TNF- $\alpha$ production are probably direct, and largely independent of IL-10 production (Procópio et al. 1999).

Another important development in the study of T. cruzi trypomastigote mucins has been that of diagnostic application. Based on the knowledge that trypanolytic antibodies found in sera from patients with chronic Chagas disease react preferentially with trypomastigote mucins, particularly with epitopes containing terminal $\alpha$-galactopyranosyl units (Almeida et al. 1991, 1993, 1994a,b) a diagnostic method has been devised using chemiluminescent (CL)-ELISA of high sensitivity and specificity (Almeida et al. 1997) which can also be used in blood bank screening. Since lytic antibodies correlate with active infection 
(Krettli \& Brener 1982, Galvão et al. 1993) the CL-ELISA method has also been used to monitor successful chemotherapy of Chagas disease in children from an endemic area (Andrade et al. 1997) and adults (unpublished). In both cases the CLELISA using purified trypomastigote mucin antigens proved to be a powerful diagnostic procedure clearly correlating negative titers with parasitological cure.

The importance of the mucin glycoproteins in T. cruzi both as constitutive structural elements in all developmental stages of the parasite and as inducers of immunological responses which can deeply affect the progression of Chagas disease is now well documented, stimulating studies to further our knowledge of their chemical characterization and functional properties.

\section{REFERENCES}

Almeida IC, Covas DT, Soussumi LM, Travassos LR 1997. A highly sensitive and specific chemiluminescent enzyme-linked immunosorbent assay for diagnosis of active Trypanosoma cruzi infection. Transfusion 37: 850-857.

Almeida IC, Ferguson MAJ, Schenkman S, Travassos LR 1994a. GPI-anchored glycoconjugates from Trypanosoma cruzi trypomastigotes are recognized by lytic anti-alpha-galactosyl antibodies isolated from patients with chronic Chagas disease. Braz J Med Biol. Res 27: 443-447.

Almeida IC, Ferguson MAJ, Schenkman S, Travassos L R 1994b. Lytic anti- $\alpha$-galactosyl antibodies from patients with chronic Chagas disease recognize novel $O$-linked oligosaccharides on mucin-like glycosylphosphatidylinositol-anchored glycoproteins of Trypanosoma cruzi. Biochem J 304: 793-802.

Almeida IC, Krautz GM, Krettli AU, Travassos LR 1993. Glycoconjugates of Trypanosoma cruzi: a $74 \mathrm{kD}$ antigen specifically reacts with lytic anti- $\alpha$-galactosyl antibodies from patients with chronic Chagas disease. J Clin Lab Anal 7: 307-316.

Almeida IC, Milani SR, Gorin PA, Travassos LR 1991. Complement-mediated lysis of Trypanosoma cruzi trypomastigotes by human anti- $\alpha$-galactosyl antibodies. J Immunol 146: 2394-2400.

Alves MJ, Colli W 1975. Glycoproteins from Trypanosoma cruzi: partial purification by gel chromatography. FEBS Lett 52: 188-190.

Brener Z, Gazzinelli RT 1997. Immunological control of Trypanosoma cruzi infection and pathogenesis of Chagas disease. Int Arch Allergy Immunol 114: 103110.

Camargo MM, Almeida IC, Pereira MES, Ferguson MAJ, Travassos LR, Gazzinelli RT 1997. GPI-anchored mucin-like glycoproteins isolated from Trypanosoma cruzitrypomastigotes initiate the synthesis of pro-inflammatory cytokines by macrophages. J Immunol 158: 5890-5901.

Camargo MM, Andrade AC, Almeida IC, Travassos LR, Gazzinelli RT 1997a. Glycoconjugates isolated from
Trypanosoma cruzi but not Leishmania species membranes trigger nitric oxide synthesis as well as microbicidal activity by IFN- $\gamma$-primed macrophages. $J$ Immunol 159: 6131-6139.

Carreira JC, Jones C, Wait R, Previato JO, MendonçaPreviato L 1996. Structural variation in the glycoinositolphospholipids of different strains of Trypanosoma cruzi. Glycoconj J 13: 955-966.

Chagas C 1909. Nova tripanozomiase humana. Estudos sobre a morfologia e o ciclo evolutivo do Schizotrypanum cruzi, gen. s.sp., agente etiológico de nova entidade mórbida do homem. Mem Inst Oswaldo Cruz 1: 159-218.

Di Noia JM, D’Orso I, Aslund L, Sanchez DO, Frasch ACC 1998. The Trypanosoma cruzi mucin family is transcribed from hundreds of genes having hypervariable regions. J Biol Chem 273: 1084310850.

Di Noia JM, Pollevick GD, Xavier MT, Previato JO, Mendonça-Previato L, Sánchez DO, Frasch ACC 1996. High diversity in mucin genes and mucin molecules in Trypanosoma cruzi. J Biol Chem 271: 32078-32083.

Di Noia JM, Sánchez DO, Frasch ACC 1995. The protozoan Trypanosoma cruzi has a family of genes resembling the mucin genes of mammalian cells. J Biol Chem 270: 24146-24149.

Ferguson MAJ 1997. The surface glycoconjugates of trypanosomatid parasites. Philos Trans $R$ SocLond B Biol Sci 352: 1295-302.

Freitas-Junior LHG, Briones MRS, Shenkman S 1998. Two distincts groups of mucin-like genes are differentially expressed in the developmental stages of Trypanosoma cruzi. Mol Biochem Parasitol 93: 101-114.

Galvão LMC, Nunes RMB, Cançado JR, Brener Z, Krettli AU 1993. Use of lytic antibodies in assessing cure after treatment of Chagas disease: a 10-year follow-up study. Trans R Soc Trop Med Hyg 87: 220223.

Gazzinelli RT, Camargo MM, Almeida IC, Morita YS, Giraldo M, Acosta-Serrano A, Hieny S, Englund PT, Ferguson MAJ, Travassos LR, Sher A 1997. Identification and characterization of protozoan products that trigger the synthesis of IL-12 by inflammatory macrophages. Chem Immunol 68: 136-152.

Haltiwanger RS, Blomberg MA, Hart GW 1992. Glycosylation of nuclear and cytoplasmic proteins. Purification and characterization of a uridine diphospho- $N$-acetylglucosamine: polypeptide $\beta-N$ acetylglucosaminyltransferase. J Biol Chem 267: 9005-9013.

Krettli AU, Brener Z 1982. Resistance against Trypanosoma cruzi associated to anti-living trypomastigote antibodies. J Immunol 128: 2009-20012.

Lederkremer RM, Alves MJM, Fonseca GC, Colli W 1976. A lipopeptidophosphoglycan from Trypanosoma cruzi (epimastigota). Isolation, purification and carbohydrate composition. Biochim Biophys Acta 444: 85-96.

Previato JO, Andrade AFB, Pessolani MCV, MendonçaPreviato L 1985. Incorporation of sialic acid into 
Trypansoma cruzi macromolecules. A proposal for a new metabolic route. Mol Biochem Parasitol 16: 85-96.

Previato JO, Jones C, Gonçalves LPB, Wait R, Travassos, LR, Mendonça-Previato L 1994. O-Glycosidically linked $\mathrm{N}$-acetylglucosamine-bound oligosaccharides from glycoproteins of Trypanosoma cruzi. Biochem J 300: 151-159.

Previato JO, Jones C, Xavier MT, Wait R, Travassos LR, Parodi AJ, Mendonça-Previato L 1995. Structural characterization of the major glycosylphosphatidylinositol membrane-anchored glycoprotein from epimastigote forms of Trypanosoma cruzi Y-strain. J Biol Chem 270: 7241-7250.

Previato JO, Sola-Penna M, Agrellos OA, Jones C, Oeltmann T, Travassos LR, Mendonça-Previato L 1998. Biosynthesis of $O-N$-acetylglucosaminelinked glycans in Trypanosoma cruzi. Characterization of the novel uridine diphospho- $N$-acetylglucosamine:polypeptide $N$-acetylglucosaminyltransferase-catalyzing formation of $\mathrm{N}$-acetylglucosamine alpha $1 \longrightarrow O$-threonine. J Biol Chem 273: 14982-14988.

Procópio DO, Teixeira MM, Camargo MM, Travassos LR, Ferguson MAJ, Almeida IC, Gazzinelli RT 1999. Differential inhibitory mechanism of cyclic AMP on TNF- $\alpha$ and IL-12 synthesis by macrophages exposed to microbial stimuli. British J Pharmacology (in press).

Reyes MB, Pollevick GD, Frasch ACC 1994. An usually small gene encodes a putative mucin-like glycoprotein in Trypanosoma cruzi. Gene 40: 139-140.

Ruiz RC, Favoreto S, Dorta ML, Oshiro ME, Ferreira AT, Manque PM, Yoshida N 1998. Infectivity of Trypanosoma cruzi strains is associated with differential expression of surface glycoproteins with differential $\mathrm{Ca}_{2}{ }^{+}$signalling activity. Biochem J 330: 505-511.

Ruiz RC, Rigoni VL, Gonzalez J, Yoshida N 1993. The $35 / 50 \mathrm{kDa}$ surface antigen of Trypanosoma cruzi metacyclic trypomastigotes, an adhesion molecule involved in host cell invasion. Parasite Immunol 15: 121-125.

Salazar NA, Mondragon A, Kelly JM 1996. Mucin-like glycoprotein genes are closely linked to members of the trans-sialidase super-family at multiple sites in the Trypanosoma cruzi genome. Mol Biochem
Parasitol 78: 127-136.

Schenkman S, Eichinger D, Pereira ME, Nussenzweig V 1994. Structural and functional properties of Trypanosoma trans-sialidase. Annu Rev Microbiol 48: 499-523.

Schenkman S, Ferguson MAJ, Heise N, Cardoso de Almeida ML, Mortara RA, Yoshida N 1993. Mucin-like glycoproteins linked to the membrane by glycosylphosphatidylinositol anchor are the major acceptors of sialic acid in a reaction catalyzed by trans-sialidase in metacyclic forms of Trypanosoma cruzi. Mol Biochem Parasitol 59: 293-304.

Schenkman S, Jiang M-S, Hart GW, Nussenzweig V 1991. A novel cell surface trans-sialidase of Trypanosoma cruzi generates a stage-specific epitope required for invasion of mammalian cells. Cell 65: 1117-1125.

Serrano AA, Schenkman S, Yoshida N, Mehlert A, Richardson JM, Ferguson MAJ 1995. The lipid structure of the glycosylphosphatidylinositol-anchored mucin-like sialic acid acceptors of Trypanosoma cruzi changes during parasite diferentiation from epimastigotes to infective metacyclic trypomastigote forms. J Biol Chem 270: 27244-27253.

Travassos LR, Almeida IC 1993. Carbohydrate immunity in American trypanosomiasis. Springer Sem Imunopathol 15: 183-204.

Travassos LR, Almeida IC, Milani SR, Gorin PAJ 1993. Antibody specificity in the conventional serology for Chagas disease. Ci Cult J Braz. Assoc Adv Sci 45: 69-73.

Yoshida N, Mortara RA, Araguth M, Gonzalez JC, Russo M 1989. Metacyclic neutralizing effect of monoclonal antibody 10D8 directed to the 35- and 50kilodalton surface glycoconjugate of Trypanosoma cruzi. Infect Immun 57: 1663-1667.

Yoshida N, Dorta ML, Ferreira AT, Oshiro ME, Mortara RA, Acosta-Serrano A, Favoreto Junior S 1997. Removal of sialic acid from mucin-like surface molecules of Trypanosoma cruzi metacyclic trypomastigotes enhances parasite-host cell interaction. Mol Biochem Parasitol 84: 57-67.

Zingales B, Carniol C, de Lederkremer RM, Colli W 1987. Direct sialic acid transfer from a protein donor to glycolipids of trypomastigote forms of Trypanosoma cruzi. Mol Biochem Parasitol 26: 13544. 